\title{
Toxicity of Baits and Their Effects on Population Suppression of Anastrepha fraterculus (Diptera: Tephritidae): Implications for Field Management
}

\author{
Marcelo Z. Nunes, ${ }^{1}$ Cleber A. Baronio, ${ }^{1}$ Inana X. Schutze, ${ }^{2, \bullet}$ Daniel Bernardi, ${ }^{2,4}$ \\ Cristiano J. Arioli, ${ }^{3}$ Ruben M. Junior, ${ }^{1}$ and Marcos Botton ${ }^{1}$
}

'Laboratório de Entomologia, Embrapa Uva e Vinho, Bento Gonçalves, RS, Brazil, ${ }^{2}$ Programa de Pós-Graduação em Fitossanidade, Universidade Federal de Pelotas, Pelotas, RS, Brazil, ${ }^{3}$ Empresa de Pesquisa Agropecuária e Extensão Rural de Santa Catarina, Estação Experimental de São Joaquim, São Joaquim, SC, Brazil, and ${ }^{4}$ Corresponding author, e-mail: dbernardi2004@yahoo.com.br

Subject Editor: Angel Acebes-Doria

Received 5 February 2020; Editorial decision 16 March 2020

\begin{abstract}
Anastrepha fraterculus (Wiedemann, 1830) is the main pest of fruit in southern Brazil. The use of toxic baits is one of the alternatives for its management. In this study, the toxic baits Anamed + malathion (10,000 mg/liter), Flyral $1.25 \%+$ malathion (2,000 mg/liter), and Gelsura (alpha-cypermethrin, 2,000 and 4,000 mg/liter) were highly toxic to the adults of $A$. fraterculus (lethal time $\left[\mathrm{LT}_{50}\right]<7 \mathrm{~h}$ ). In contrast, Success $0.02 \mathrm{CB}$ had an $\mathrm{LT}_{50}$ of $48.4 \mathrm{~h}$. In the absence of rain, all the formulations had residual effects ( $>90 \%$ mortality) on $A$. fraterculus adults up to $21 \mathrm{~d}$ after treatment (DAT). In the presence of 5,25 , and $50 \mathrm{~mm}$ of rainfall, there was a significant reduction in the residual effect over time. However, with up to $50 \mathrm{~mm}$ of rain, Anamed + malathion and Gelsura 2,000 and 4,000 mg/liter caused between 43.0 and $79.0 \%$ of mortality. In the field, during two consecutive seasons (2015/2016 and 2016/2017), applications of Gelsura 2,000 mg/liter (four applications/season) caused population suppression of the pest throughout the apple fruiting period. However, in the $2016 / 2017$ season, in the area using Gelsura, a higher percentage $(\approx 12 \%)$ of apple fruits damaged by $A$. fraterculus females was observed when compared with the area with insecticide application (damage $<3 \%)$. The toxic bait Gelsura $(2,000$ and $4.000 \mathrm{mg} / \mathrm{liter}$ ) was shown to be promising for use in the management of $A$. fraterculus, with results similar to those with the application of synthetic insecticides.
\end{abstract}

Key words: South American fruit fly, integrated pest management, rain effect, chemical control

Population suppression of fruit flies through behavioral manipulation using toxic baits (food attractant + lethal agent mix) has become an important component of integrated pest management (IPM) programs worldwide (Stark et al. 2004, Chueca et al. 2007, Flores et al. 2011, Gazit et al. 2013, Navarro-Llopis et al. 2013, Botton et al. 2016, Yee and Alston 2016, Raga and Galdino 2018, Baronio et al. 2019). The principle of the use of toxic baits is to control the adults of the pest because the females need to ingest carbohydrates and proteins for ovarian development before ovipositing on the fruits and consequently also ingest the lethal agent (Bateman and Morton 1981).

Although studies show a high toxicity of baits to fruit fly species, the vast majority of Brazilian fruit producers, especially apple, peach, and citrus growers, advocate the use of chemical insecticides with full area coverage (Botton et al. 2016, Raga and Galdino 2018) and mainly support the use of phosphorous insecticides (e.g., phosmet and malathion) (Raga and Galdino 2018). This fact is associated with the broad spectrum of activity for these insecticides, which in addition to causing adult mortality, act in the egg and larval stage with residual effects greater than $21 \mathrm{~d}$ (Raga and Galdino 2018). In addition, the low residual effect of toxic bait formulations after rainfall has been one of the reasons for the low adoption in orchards (Revis et al. 2004, Mangan et al. 2006, Flores et al. 2011, Piñero et al. 2011, Gazit et al. 2013, Mafra-Neto et al. 2013, Baronio et al. 2018).

However, in recent studies, it has been found that the Gelsura toxic bait formulation (gel formulation) (6 g/liter of alpha-cypermethrin) (BASF S/A, Guaratinguetá, São Paulo State, Brazil), which is in the registration phase in Brazil for the management of fruit flies, has shown high toxicity to adults of Ceratitis capitata and other fruit fly species (Vargas et al. 2018, Baronio et al. 2019). The bait consists of a protein-based food attractant in a polymer matrix (SPLAT), which provides relatively high resistance to sunlight and rain degradation (Broughton and Rahman 2017, Baronio et al. 2019). This was also shown with the Anamed formulation (a waxy formulation) (Isca Tecnologias Ltda., Ijuí, RS, Brazil) (Mafra-Neto et al. 2013, Borges et al. 2015). 
Based on this, the aim of this study was to evaluate the toxicity and residual effect of toxic bait formulations on adults of Anastrepha fraterculus in the absence and presence of simulated rain. Additionally, the efficacy of Gelsura bait in field pest suppression, in comparison with that of chemical insecticides, was validated.

\section{Material and Methods}

Insects

The insects used in the bioassays were collected from strawberry guava, Psidium cattleianum, fruits infested with $A$. fraterculus larvae from plants and orchards in Bento Gonçalves, Rio Grande do Sul State, Brazil $\left(29^{\circ} 09^{\prime} 48.75^{\prime \prime} \mathrm{S}, 51^{\circ} 31^{\prime} 44.80^{\prime \prime} \mathrm{W}\right)$. In the laboratory, the larvae and adults were reared and multiplied for nine generations according to the methodology proposed by Machota Jr. et al. (2010). For all the bioassays, adults of $A$. fraterculus up to $14 \mathrm{~d}$ old were deprived of food for $12 \mathrm{~h}$ prior to the provision of the toxic bait formulations.

\section{Treatment Description}

For the bioassays, two ready-to-use toxic baits were used: Success 0.02 CB (0.24 g/liter of spinosad) (Corteva Agriscience, Santo Amaro, São Paulo State, Brazil) and Gelsura (6 g/liter of alpha-cypermethrin) (BASF S/A, Guaratinguetá, São Paulo State, Brazil). Two food lures were used: Anamed (40\% SPLAT $+24.2 \%$ food attractant containing fruit extracts and phagostimulants, Isca Tecnologias Ltda., Ijuí, RS, Brazil) and Flyral 1.25\% commercial product (enzymatic hydrolyzed protein of animal origin, Biolbérica S.A., Barcelona, Spain). These food lures were used in the toxic bait formulations with the insecticide Malathion 1000 EC (malathion 1,000 g a.i. (active ingredient)/liter) (Cheminova Ltda., São Paulo, São Paulo State, Brazil). The treatments were as follows: T1- and T2-contained diluted Gelsura toxic bait (one part commercial product to two parts water or two parts commercial product to one part water, resulting in solutions with 2,000 and 4,000 mg/liter alpha-cypermethrin, respectively); T3 contained diluted Success $0.02 \mathrm{CB}$ toxic bait (one part commercial product to 1.5 parts water (based on the product recommendations), resulting in a solution with $96 \mathrm{mg} /$ liter of spinosad); T4 contained Anamed + Malathion 1000 EC (10,000 mg/liter of malathion); T5 contained Flyral $1.25 \%$ + Malathion 1000 EC (2,000 mg/liter of malathion); and $\mathrm{T} 6$ was the negative control (water).

\section{Lethal Time of the Toxic Baits to A. fraterculus Adults in the Laboratory}

Six adults of $A$. fraterculus (three males and three females) from the maintenance rearing stock were kept on filter paper inside bioassay cages made from inverted plastic containers $(300 \mathrm{ml})$ as described by Baronio et al. (2019). To estimate the mean lethal time $\left(\mathrm{LT}_{50}\right)$, i.e., the time required to kill $50 \%$ of the population, $40 \mu$ of the toxic baits was applied to plastic plates $\left(1 \mathrm{~cm}^{2}\right)$ by using a graduated single-channel micropipette (Gilson Pipetman U76928A) with a $1 \mathrm{ml}$ capacity (Baronio et al. 2019). After $2 \mathrm{~h}$ (the time required for treatment drying and residue deposition), A. fraterculus adults were exposed to the treatments for $2 \mathrm{~h}$. Next, the treatments were removed, and the insects were fed an artificial diet $(5 \mathrm{~g})$ composed of soybean extract, wheat germ and brown sugar at a ratio of 3:1:1 (Nunes et al. 2013). The experimental design was completely randomized with 6 treatments and 20 replications (cages) by treatment, each with 6 insects $(n=120)$. To estimate the $\mathrm{LT}_{50}$ values, insect mortality was assessed every $2 \mathrm{~h}$ within the first $24 \mathrm{~h}$ and every $24 \mathrm{~h}$ thereafter until $96 \mathrm{~h}$ after the insect release. The insects were considered dead when they did not react to the touch of a fine-tipped brush. The bioassays were maintained in a climatized room at $25 \pm 2{ }^{\circ} \mathrm{C}, 70 \pm 10 \%$ relative humidity and a $12 \mathrm{~h}$ photoperiod.

\section{Toxicity and the Residual Effect of Toxic Baits on A. fraterculus in the Absence of Rain}

Citrus plants of the cultivar Valencia were grown in plastic buckets (20 liters) filled with plant substrate and soil (1:1 ratio) (one plant per pot). After acclimatization of the plants inside a greenhouse, one drop $(40 \mu \mathrm{l})$ of toxic bait (treatment) was applied to each leaf with a $50 \mathrm{ml}$ graduated syringe. After $0(2 \mathrm{~h}), 7,14$, and $21 \mathrm{~d}$ after the application of the treatments (DATs), 10 sheets containing toxic baits were transported to the laboratory and packed inside the bioassay cages as described above. Five pairs of A. fraterculus were released per cage for a period of $24 \mathrm{~h}$. After the $24 \mathrm{~h}$ exposure time, the toxic baits were removed, and the insects were fed an artificial diet until the end of the evaluations. The experimental design was completely randomized, with 6 treatments and 10 replications (cages) per treatment $(n=100)$ for each evaluation period of the toxic bait leaves. Adult mortality of $A$. fraterculus was assessed $96 \mathrm{~h}$ after the release of the insects into the cages. The insects were considered dead when they did not react to the touch of a fine-tipped brush. The efficacy of each treatment was calculated by Abbott formula (1925).

\section{Toxicity and the Residual Effect of the Toxic Baits on A. fraterculus in the Presence of Simulated Rain}

Citrus plants of the cultivar Valencia were grown as previously described. Subsequently, a plastic syringe $(50 \mathrm{ml})$ was used to apply drops $(40 \mu \mathrm{l})$ of toxic bait (treatment) to the leaves (one drop per leaf). Two hours after the application, the plants containing the treatments were positioned under rain simulation equipment, consisting of a rectangular frame $(1.35 \mathrm{~m}$ per $1.75 \mathrm{~m})$ equipped with six fan-type nozzles (Magno Jet [AD-IA 110-015]; Magno Jet, Ibaiti, Paraná, Brazil) set at a height of $2.3 \mathrm{~m}$ from ground level. The transverse movement of the equipment was performed with electric energy, covering an area of $2.83 \mathrm{~m}^{2}$. The working pressure used in the rain simulator was $15 \mathrm{lb}$, which generated rainfall depths of 5,25 , and $50 \mathrm{~mm}$ at a fixed rainfall intensity of $50 \mathrm{~mm} \cdot \mathrm{h}^{-1}$. After 0 (2 h), 7, 14, and 21 DATs, 10 sheets containing the toxic baits were transported to the laboratory and placed inside the bioassay cages. Subsequently, five $A$. fraterculus pairs were released per cage following the methodology described above. The experimental design was completely randomized with 10 replications (cages) per treatment, and each replication consisted of 5 A. fraterculus pairs ( $n=100)$ per leaf collection period. The evaluation time and adult mortality criteria were similar to those described above. The efficacy of each treatment was calculated by Abbott formula (1925).

\section{A. fraterculus Population Suppression in the Field}

This study was conducted in the area of two apple orchards located in Vacaria, RS, Brazil $\left(31.7719^{\circ} \mathrm{S}, 52.3425^{\circ} \mathrm{W}\right)$, during two consecutive season, 2015/2016 and 2016/2017. The orchards, which had a history of $A$. fraterculus natural infestations, were composed of the apple cultivar Royal Gala, cultivated with a spacing of 1.8 $\mathrm{m}$ per $4.5 \mathrm{~m}$ (row and row, respectively). For this experiment, two treatments $(\mathrm{T})$ were carried out: T1 (area 1), covering approximately 1.3 hectares, in which insecticides were applied (three applications) 
in a spray volume of 1,000 liter per hectare with a turbo atomizer. The insecticides used were Suprathion 500 EC (Adama Brasil, Londrina Parana, Brazil) (5 ml a.i. per 100 liter water), Mospilan 20 SP (Iharabras, Sorocaba, Brazil) $(0.8 \mathrm{ml}$ a.i. per $100 /$ liter $)$ and Imidan 500 WP (Cross Link Consultoria e Comércio Ltda, Barueri, São Paulo, Brazil (75 g a.i. per 100/liter). T2 (area 2), covering approximately 1.6 hectares, in which the toxic bait Gelsura $(2,000 \mathrm{mg} /$ liter) was used. The toxic bait applications (four applications with $10 \mathrm{~d}$ between each application) were performed using a Jacto electric backpack sprayer (Jacto Agricultural Machines, Pompeii, Sao Paulo, Brazil) with a 15-liter reservoir. The application volume was 4.81 per hectare, totaling 400 application points per hectare. The bait application points were directed at the top of the stem of the plants $(12 \mathrm{ml}$ per plant), at the intersection between branches, to provide greater protection of the product from rain wash. For both treatments, the experimental design was a randomized complete block design, with four replicates (approximately 0.4 ha per replication) per treatment.

\section{Monitoring of A. fraterculus Adults and Evaluation of the Fruit Damage}

To evaluate the $A$. fraterculus infestation in the experimental areas (areas 1 and 2), McPhail traps (Isca Technologies, Ijuí, RS, Brazil) baited with Ceratrap food attractant (Biolbérica SA, Barcelona, Spain) (500 $\mathrm{ml}$ per trap), considered the most efficient food attractant for the capture of A. fraterculus (Bortoli et al. 2016), were used. The traps were placed in the quadrants of each area. The number of $A$. fraterculus adults throughout the harvest was assessed by counting the number of trapped insects twice a week. The food attractant was replaced when the volume was below $250 \mathrm{ml}$ per trap. All the flies captured in the monitoring traps were removed from traps weekly, emptied into individually identified paper bags, and counted in the laboratory. In each area and crop evaluated, a random collection of 500 apple fruits (125 fruits per repetition-four fruits per tree) was performed directly from the plant in three maturation periods: preharvest, full harvest, and final harvest. Fruits harvested from each repetition were labeled, stored in plastic boxes (10 liters) and taken to the laboratory. In the laboratory, the fruits were kept in an air-conditioned room (150 fruits per box). After $15 \mathrm{~d}$, the period necessary to develop the larvae until the third instar (Nunes et al. 2013), the fruits were cut to verify the presence of galls caused by the larvae (Machota Jr. et al. 2016).

\section{Statistical Analysis}

To estimate the $\mathrm{LT}_{50}$ and respective confidence intervals (95\% FL), the insect mortality data in each treatment were tested with a probit analysis (PROC PROBIT, SAS Institute, 2011). A probability test (F-test) was conducted to test the hypothesis that the LT values were equal. If the hypothesis was rejected, pairwise comparisons were performed, and significance was assumed when there was no overlap of the confidence intervals (Robertson and Preisler 2007). For the evaluation of the toxicity of the toxic baits and the residual effect in the absence and presence of simulated rain, the data on the survival rates of the A. fraterculus adults that did not present a normal distribution were transformed with a Box-Cox transformation prior to the analyses. Subsequently, a two-way analysis of variance was performed on all the data using PROC GLM. The differences between the treatments were determined by the least-squares means (PDIFF option in PROC GLM) followed by Tukey's adjustment based on a $5 \%$ significance (SAS Institute, 2011). A log-complement transformation was used to transform the data obtained from the capture of A. fraterculus in the different treatments in the field to meet the normality assumptions, based on the Shapiro-Wilk test, and homogeneity assumptions, based on the Bartlett test. Subsequently, the mean values were assessed with an analysis of variance (ANOVA) and $F$ test $(P \leq 0.05)$. When statistically significant, the mean values were compared with a $t$-test $(P \leq 0.05)$. The number of damaged apples between the treatments within each harvest and year was determined by Student's $t$-test. All the analyses were performed using SAS statistical software (SAS Institute 2011).

\section{Re`sults}

Based on overlapping confidence intervals, the toxic baits Anamed + malathion $\left(\mathrm{LT}_{50}[95 \%\right.$ confidence interval $\left.\{\mathrm{CI}\}]=3.18[2.15-4.78] \mathrm{h}\right)$, Flyral $1.25 \%+$ malathion $\left(\mathrm{LT}_{50}[95 \% \mathrm{CI}]=1.18[0.90-2.95] \mathrm{h}\right)$, and Gelsura (alpha-cypermethrin, 2,000 and 4,000 mg/liter) $\left(\mathrm{LT}_{50}[95 \% \mathrm{CI}]=6.05[3.11-6.64] \mathrm{h}\right.$ and $\mathrm{LT}_{50}[95 \% \mathrm{CI}]=2.97$ [2.80-4.98] h for the 2,000 and 4,000 mg/liter treatments, respectively) showed higher toxicity on $A$. fraterculus adults in a shorter period $(\mathrm{LT}<7 \mathrm{~h}$ ) when compared with the toxicity of Success $0.02 \mathrm{CB}$ $($ spinosad $)\left(\mathrm{LT}_{50}[95 \% \mathrm{CI}]=48.40[43.40-52.51] \mathrm{h}\right.$; Table 1).

When evaluating the residual effect in the absence of rain, it was determined that all the toxic bait formulations caused greater than $90 \%$ mortality of $A$. fraterculus adults up to 21 DAT. The results were not statistically different within the evaluation times: 0 $\left(F_{4,44}=15.72 ; P=0.5612\right), 7\left(F_{4,44}=18.00 ; P=0.1423\right), 14$ $\left(F_{4,44}=10.21 ; P=0.0876\right)$, and $21 \mathrm{DAT}\left(F_{4,44}=15.19 ; P=0.0 .0985\right.$; Table 2). Additionally, the results over time within the same treatment are as follows: Anamed + malathion $\left(F_{3,36}=4.75 ; P=0.0654\right)$, Flyral $1.25 \%+$ malathion $\left(F_{3,36}=10.11 ; P=0.0871\right)$, Gelsura $2,000\left(F_{3,36}=10.12 ; P=0.0754\right)$, Gelsura 4,000 $\left(F_{3,36}=10.12\right.$; $P=0.0875)$, and Success $0.02 \mathrm{CB}\left(F_{3,36}=7.15 ; P=0.1245\right.$; Table 2$)$. In contrast, in the presence of simulated rain $(5,25$, and $50 \mathrm{~mm})$, all the toxic baits showed a significant reduction in toxicity to $A$. fraterculus adult (Table 3). However, in the presence of $25 \mathrm{~mm}$ of rain, the Anamed + malathion and Gelsura 4,000 mg formulations provided between 65 and $83 \%$ mortality of the insects, similar to effect of the toxic bait Gelsura 2,000 mg with $50 \mathrm{~mm}$ of rain (Table 3).

Table 1. Lethal time $\left(\mathrm{LT}_{50}\right)$ of toxic bait formulations on Anastrepha fraterculus adults in laboratory

\begin{tabular}{lcccc}
\hline Treatment & Dose (mg/liter) & Slope \pm SE & LT $_{50}(95 \% \text { FL) (hours) })^{a}$ & $\chi^{2 b}$ \\
\hline Anamed + malathion & 10,000 & $1.18 \pm 0.08$ & $3.18(2.15-4.78) \mathrm{b}$ & 6.50 \\
Flyral 1.25\% + malathion & 2,000 & $1.22 \pm 0.09$ & $1.18(0.90-2.95) \mathrm{b}$ & 11 \\
Success 0.02CB (spinosad) & 96 & $2.44 \pm 0.14$ & $48.40(43.41-52.51) \mathrm{a}$ & 6.11 \\
Gelsura (alpha-cypermethrin) & 2,000 & $1.88 \pm 0.08$ & $6.05(3.11-6.64) \mathrm{b}$ & 11 \\
Gelsura (alpha-cypermethrin) & 4,000 & $2.43 \pm 0.08$ & $2.97(2.80-4.98) \mathrm{b}$ & 11 \\
\hline
\end{tabular}

${ }^{a} \mathrm{LT}_{50}$ : Lethal time required to kill $50 \%$ of the adults of C. capitata, respectively (CI: confidence interval at $95 \%$ error probability; ${ }^{b} \chi 2$ : Pearson's $\chi^{2}$ value; ${ }^{c} \mathrm{df}$ : degrees of freedom. 
Table 2. Mean number of alive insects $(N \pm \mathrm{SE})$ and mortality (\%) of Anastrepha fraterculus adults exposed to toxic baits applied on citrus leaves aged in a dry environment for $0,7,14$, and $21 \mathrm{~d}$

\begin{tabular}{|c|c|c|c|c|c|c|c|c|c|c|}
\hline \multirow[t]{2}{*}{ Treatment } & \multirow{2}{*}{$\begin{array}{c}\text { Dose } \\
\text { (mg/liter) }\end{array}$} & \multicolumn{2}{|c|}{0 DAT } & \multicolumn{2}{|c|}{7 DAT } & \multicolumn{2}{|c|}{14 DAT } & \multicolumn{2}{|c|}{21 DAT } & \\
\hline & & $N \pm \mathrm{SE}^{a}$ & $\mathrm{M} \%^{b}$ & $N \pm \mathrm{SE}^{a}$ & $\mathrm{M} \%$ & $N \pm \mathrm{SE}^{a}$ & $\mathrm{M} \%$ & $N \pm \mathrm{SE}^{a}$ & $\mathrm{M} \%$ & \\
\hline Anamed + malathion & 10,000 & $0.1 \pm 0.1 \mathrm{Aa}$ & 99.0 & $0.1 \pm 0.1 \mathrm{Aa}$ & 99.0 & $0.1 \pm 0.1 \mathrm{Aa}$ & 99.0 & $0.0 \pm 0.0 \mathrm{Aa}$ & 100.0 & $\begin{array}{l}F_{3,36}=4.75 ; \\
P=0.0654\end{array}$ \\
\hline Flyral $1.25 \%$ + malathion & 2,000 & $0.4 \pm 0.2 \mathrm{Aa}$ & 96.0 & $1.0 \pm 0.4 \mathrm{Aa}$ & 90.0 & $0.1 \pm 0.1 \mathrm{Aa}$ & 99.0 & $0.4 \pm 0.2 \mathrm{Aa}$ & 96.0 & $\begin{array}{l}F_{3,36}=10.11 ; \\
P=0.0871\end{array}$ \\
\hline Gelsura (alpha-cypermethrin) & 2,000 & $0.2 \pm 0.0 \mathrm{Aa}$ & 98.0 & $0.2 \pm 0.1 \mathrm{Aa}$ & 98.0 & $0.2 \pm 0.2 \mathrm{Aa}$ & 98.0 & $0.2 \pm 0.1 \mathrm{Aa}$ & 98.0 & $\begin{array}{l}F_{3,36}=10.12 ; \\
P=0.0754\end{array}$ \\
\hline Gelsura (alpha-cypermethrin) & 4,000 & $0.3 \pm 0.0 \mathrm{Aa}$ & 97.0 & $0.0 \pm 0.0 \mathrm{Aa}$ & 100.0 & $0.2 \pm 0.1 \mathrm{Aa}$ & 98.0 & $0.0 \pm 0.0 \mathrm{Aa}$ & 100.0 & $\begin{array}{l}F_{3,36}=12.27 ; \\
P=0.0875\end{array}$ \\
\hline Success $0.02 \mathrm{CB}$ (spinosad) & 96 & $0.2 \pm 0.1 \mathrm{Aa}$ & 98.0 & $0.0 \pm 0.0 \mathrm{Aa}$ & 100.0 & $1.8 \pm 0.8 \mathrm{Aa}$ & 82.0 & $0.6 \pm 0.3 \mathrm{Aa}$ & 94.0 & $\begin{array}{l}F_{3,36}=7.15 \\
P=0.1245\end{array}$ \\
\hline \multirow[t]{3}{*}{ Values } & F & 15.72 & & 18.00 & & 10.21 & & 15.19 & & \\
\hline & df & 4,44 & & 4,44 & & 4,44 & & 4,44 & & \\
\hline & $P$ & 0.5612 & & 0.1423 & & 0.0876 & & 0.0985 & & \\
\hline
\end{tabular}

${ }^{a}$ Mean followed by uppercase letters in the column and lowercase letters in the row do not differ by Tukey test at $5 \%$ significance.

${ }^{b}$ Mortality calculated using Abbott's formula (1925).

Table 3. Number of live insects (mean \pm SE) and mortality (\%) of Anastrepha fraterculus adults after $96 \mathrm{~h}$ of exposure to toxic bait residues exposed to simulated rain $(0,5,25$, and $50 \mathrm{~mm})$ on intensity of $50 \mathrm{~mm} \cdot \mathrm{h}^{-1}$

\begin{tabular}{|c|c|c|c|c|c|c|c|c|}
\hline \multirow[t]{2}{*}{ Treatment } & \multirow{2}{*}{$\begin{array}{c}\text { Dose } \\
\text { (mg/liter) }\end{array}$} & \multicolumn{2}{|c|}{$5 \mathrm{~mm}$} & \multicolumn{2}{|c|}{$25 \mathrm{~mm}$} & \multicolumn{2}{|c|}{$50 \mathrm{~mm}$} & \\
\hline & & $N \pm \mathrm{SE}^{a}$ & $\mathrm{M} \%^{b}$ & $N \pm \mathrm{SE}^{a}$ & $\mathrm{M} \%$ & $N \pm \mathrm{SE}^{a}$ & $\mathrm{M} \%$ & \\
\hline Anamed + malathion & 10,000 & $0.8 \pm 0.6 \mathrm{Aa}$ & 92.0 & $3.5 \pm 0.9 \mathrm{ABab}$ & 65.0 & $4.6 \pm 1.8 \mathrm{Ab}$ & 54.0 & $\begin{array}{l}F_{2,24}=2.39 ; \\
P<0.0001\end{array}$ \\
\hline Flyral $1.25 \%$ + malathion & 2,000 & $9.1 \pm 0.3 \mathrm{Ba}$ & 9.0 & $9.5 \pm 0.2 \mathrm{Ca}$ & 5.0 & $9.2 \pm 0.3 \mathrm{Ba}$ & 8.0 & $\begin{array}{l}F_{2,24}=7.11 ; \\
P=0.0897\end{array}$ \\
\hline Success $0.02 \mathrm{CB}$ (spinosad) & 96 & $9.2 \pm 0.2 \mathrm{Ba}$ & 8.0 & $9.5 \pm 0.3 \mathrm{Ca}$ & 5.0 & $9.5 \pm 0.6 \mathrm{Ba}$ & 5.0 & $\begin{array}{l}F_{2,24}=8.13 ; \\
P=0.0522\end{array}$ \\
\hline Gelsura (alpha-cypermethrin) & 2,000 & $0.5 \pm 0.3 \mathrm{Aa}$ & 95.0 & $5.9 \pm 0.9 \mathrm{Bb}$ & 41.0 & $5.7 \pm 0.6 \mathrm{Ab}$ & 43.0 & $\begin{array}{l}F_{2,24}=4.12 ; \\
P<0.0001\end{array}$ \\
\hline Gelsura (alpha-cypermethrin) & 4,000 & $1.3 \pm 0.4 \mathrm{Aa}$ & 87.0 & $1.7 \pm 0.7 \mathrm{Aa}$ & 83.0 & $2.1 \pm 0.6 \mathrm{Aa}$ & 79.0 & $\begin{array}{l}F_{2,24}=7.94 ; \\
P=0.0675\end{array}$ \\
\hline \multirow[t]{3}{*}{ Values } & $F$ & 9.72 & & 11.10 & & 8.16 & & \\
\hline & df & 4,44 & & 4,44 & & 4,44 & & \\
\hline & $P$ & $<0.0001$ & & $<0.0001$ & & $<0.0001$ & & \\
\hline
\end{tabular}

${ }^{a}$ Mean followed by uppercase letters in the column and lowercase letters in the row do not differ by Tukey test at $5 \%$ significance.

${ }^{b}$ Mortality calculated using Abbott's formula (1925).

In the field, after four applications at 10-d intervals, the Gelsura $2,000 \mathrm{mg}$ formulation, which is considered promising in the management of fruit flies and has similar toxicity and residual effects as those of Anamed + malathion (comparison standard) reported in previous bioassays, maintained the population of $A$. fraterculus below the control level (CL) (CL: 0.5 flies per trap per day) during all periods and season studied in 2015/2016 (Fig. 1) and 2016/2017 (Fig. 2). In addition, during the 2015/2016 and 2016/2017 seasons, the Gelsura toxic bait provided a greater reduction in the $A$. fraterculus population at the designated end-of-harvest period than that in areas with insecticide applications (Figs 1 and 2). For the 2015/2016 season, the apple fruit damage was less than 5\% in all the treatments (areas 1 and 2), with no significant differences between the preharvest $(t=10.44, \mathrm{df}=1,244, P=0.0473)$, full harvest $(t=16.11, \mathrm{df}=1,244, P=0.1235)$, and end of harvest $(t=9.11$, $\mathrm{df}=1,244, P=0.0519$; Fig. $3 \mathrm{~A}$ ) periods evaluated. However, in the
2016/2017 season, the area with Gelsura application presented a higher percentage of fruits damaged by $A$. fraterculus for the periods corresponding to full harvest ( $4 \%$ damage $)(t=12.99, \mathrm{df}=1,244$; $P<0.0001)$ and end of harvest (12\% damage) $(t=7.15, \mathrm{df}=1,244$; $P<0.0001)$ compared with the fruits collected in the area with insecticide application (damage below $3 \%$; Fig. 3B).

\section{Discussion}

The adults of $A$. fraterculus exposed to toxic bait formulations containing the lethal malathion agents (Anamed + malathion 10,000 mg/ liter and Flyral $1.25 \%$ + malathion $(2,000 \mathrm{mg} /$ liter $)$, alpha-cypermethrin (Gelsura-2,000 and 4,000 mg/liter) and spinosad (Success $0.02 \mathrm{CB}-96 \mathrm{mg} /$ liter) were highly susceptible to mortality after ingestion. The Success $0.02 \mathrm{CB}$ formulation had the highest mean lethal time $\left(\mathrm{LT}_{50}\right)$. This longer time compared to those of the other 


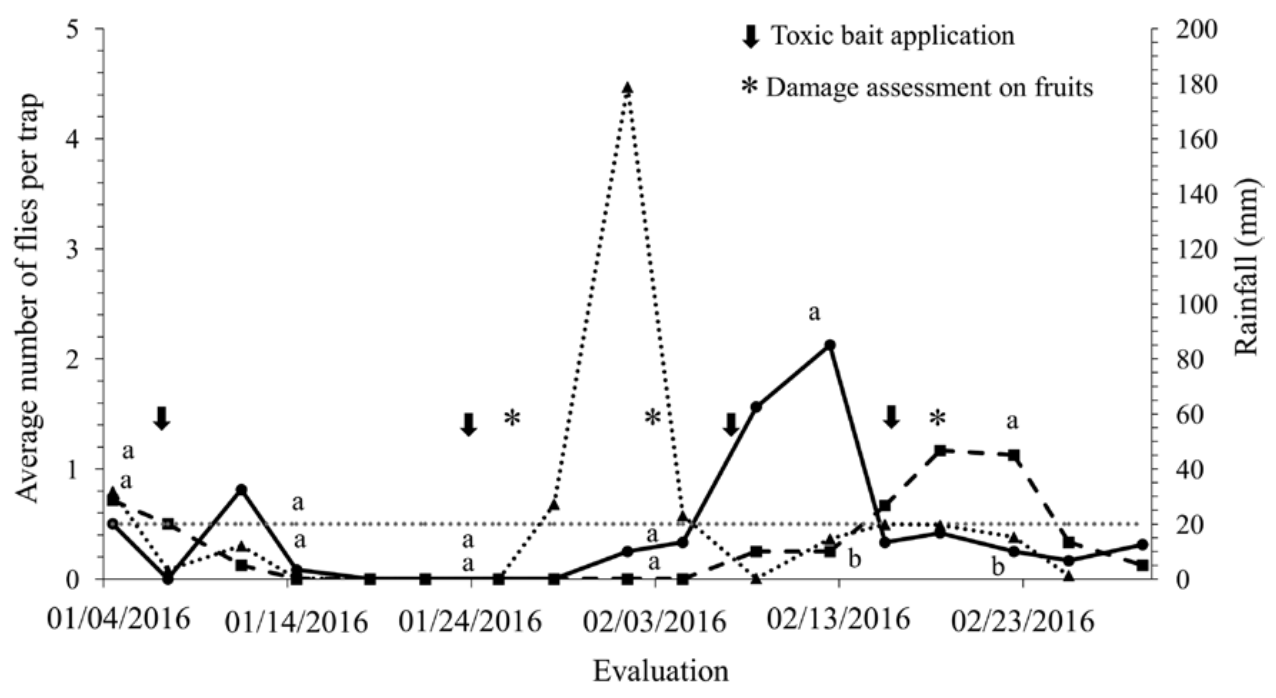

-- Gelsura ${ }^{\mathrm{TM}}$ (alpha-cypermethrin) $\bullet$ Conventional management $\cdots \cdots \cdot$ Level of control $\cdot \cdots \cdot \cdot$ Rainfall (mm)

Fig. 1. Average number of Anastrepha fraterculus adults (average \pm standard error) captured during the period the $2015 / 2016$ season. The 'days' lines followed by the same letter do not significantly differ as determined by the Tukey test $(P>0.05)$.

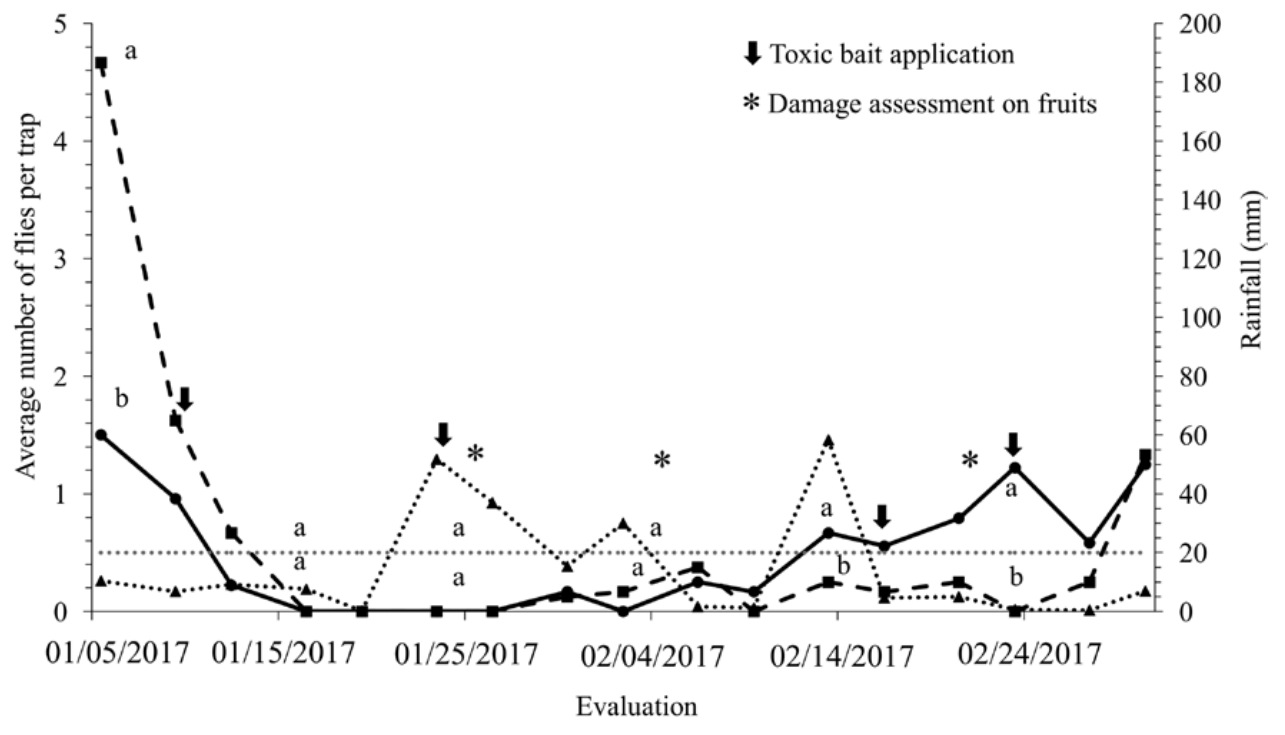

- Gelsura ${ }^{\mathrm{TM}}($ alpha-cypermethrin) $\rightarrow$ Conventional management $\cdots \cdots \cdot$ Level of control $\cdots * \cdot$ Rainfall $(\mathrm{mm})$

Fig. 2. Average number of Anastrepha fraterculus adults (average \pm standard error) captured during the period the $2016 / 2017$ season. The 'days' lines followed by the same letter do not significantly differ as determined by the Tukey test $(P>0.05)$.

formulations is attributed to the mode of action of spinosad, which, despite showing a contact effect, causes mortality more slowly when ingested (Galm and Sparks 2015). In contrast, malathion and alpha-cypermethrin, in addition to having an ingestion effect, are potentiated by contact action (Galm and Sparks 2015). Understanding lethal time is of paramount importance for the management of fruit flies with toxic baits, since the faster the action, the lower the chances of the females flying away after ingesting the product to seek fruits for oviposition (Galm and Sparks 2015, Yee and Alston 2016).

Although all the toxic baits evaluated showed residual effects and high toxicity (mortality up to $90 \%$ at 21 DATs) to adults of A. fraterculus in the absence of rain, one of the perceived limitations reported in several studies (Revis et al. 2004, Flores et al. 2011, Allen et al. 2015) was the low residual effect of the toxic baits in the presence of rain. In the present study, a $5 \mathrm{~mm}$ rainfall depth applied at an intensity of $50 \mathrm{~mm} \cdot \mathrm{h}^{-1}$ totally washed away the Flyral + malathion and Success $0.02 \mathrm{CB}$ formulations applied to citrus leaves. However, the formulations composed of the Anamed and Gelsura attractants resisted the impact of up to $50 \mathrm{~mm}$ of rainfall and produced mortality ranging from 43 to $79 \%$ of $A$. fraterculus adults.

The low resistance of liquid toxic baits such as Flyral and Success $0.02 \mathrm{CB}$ to rain may be associated with the components present in food attractants, such as sugars and hydrolyzed proteins. These materials are easily dissolved in the presence of water, making them inefficient for adult attraction and, therefore, lowering their target toxicity (Revis et al. 2004, Flores et al. 2011, Harter et al. 2015). In 


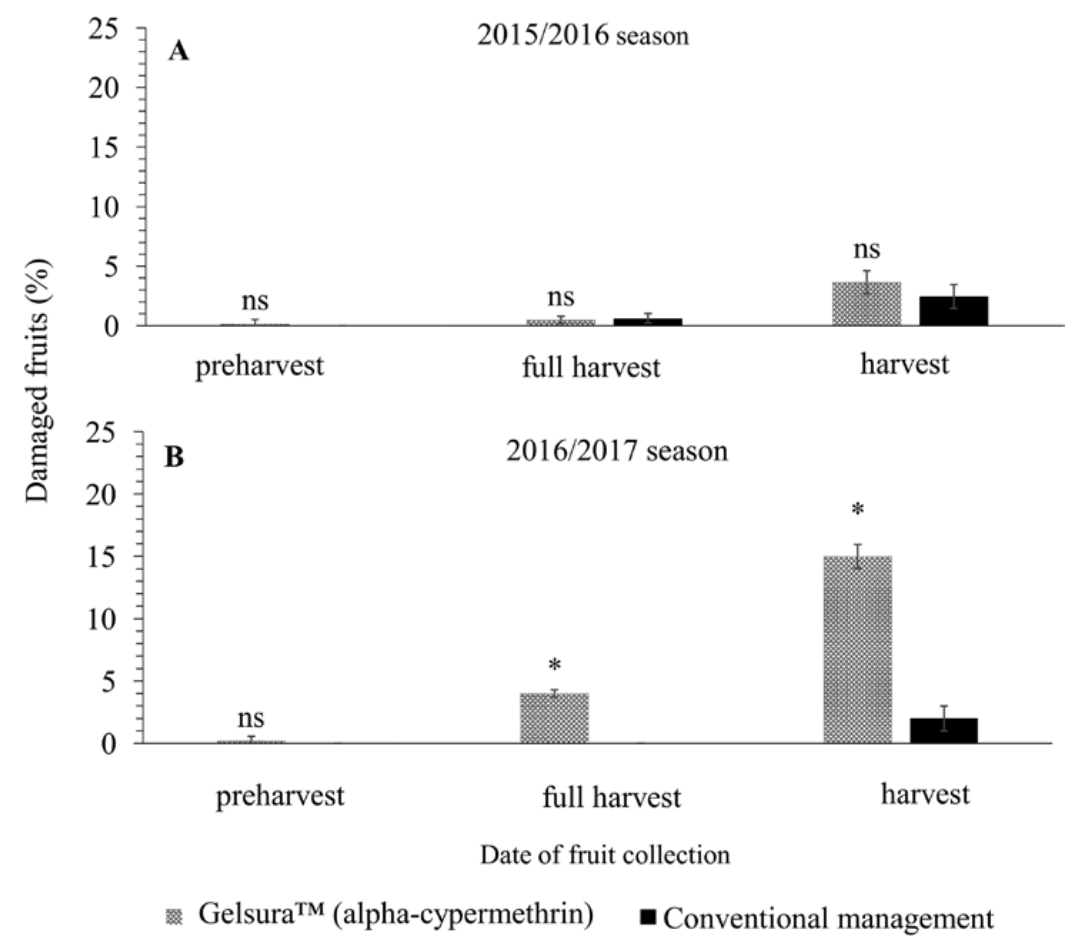

Fig. 3. Percentage of apple fruit damage by Anastrepha fraterculus in the evaluations during the period 2015/2016 and $2016 / 2017$ harvest. ${ }^{\text {ns. }}$ not significant when comparing the two treatments within the same period of harvest by Student's $t$-test. *significant when comparing the two treatments within the same period of harvest by Student's $t$-test.

contrast, toxic baits in waxy (Anamed) or gel (Gelsura) formulations showed a higher resistance to rainwater washing, maintaining their effectiveness for a longer time after application (Mafra-Neto et al. 2013, Baronio et al. 2019).

Although liquid formulations have a low residual effect on target pests in the presence of rain, they should not be discarded for use in fruit fly management. However, the climatic factors of the target region should be considered in the decision making process (Revis et al. 2004, Mangan et al. 2006, Flores et al. 2011, Piñero et al. 2011, Gazit et al. 2013, Mafra-Neto et al. 2013, Baronio et al. 2019). Thus, in regions with high rainfall, such as in the South Region of Brazil, if a producer chooses to use toxic baits with liquid formulations, applications should be performed frequently, taking into account the results obtained in the present study.

In the field, it was found that after four applications of Gelsura (10-d intervals), the $A$. fraterculus population remained below the CL established for A. fraterculus in Brazil ( $C L<0.5$ flies per day) throughout the evaluation period (preharvest, full harvest, and final harvest) based on McPhail traps (Nava and Botton 2010). In contrast to areas with insecticide applications, there were population peaks of $A$. fraterculus that were higher than the CL, especially in the designated end of harvest period. This was due to the low contact effect provided by the application of the acetamiprid insecticide (a neonicotinoid) during this harvest period (Nondillo et al. 2007). In addition, the presence of native plants, such as Surinam cherry (Eugenia uniflora) and strawberry guava (Psidium cattleianum), which vastly increase the populations of $A$. fraterculus in the field (Gattelli et al. 2008), close to the study area may have favored adult migration of A. fraterculus into the area (Pereira-Rêgo et al. 2013).

Although, in the 2016/2017 season the adult population remained below the CL in the Gelsura application area, there was a higher percentage of damaged fruit than that in the conventional area. This fact may be associated with the bioecological behavior of A. fraterculus females, as verified by Bactrocera dorsalis (Handel, 1912) and Bactrocera curcubitae (Coquillett) (Diptera: Tephritidae), which presented a greater attraction and response to odors released by fruits used in toxic bait (Miller et al. 2004). In addition, throughout the apple fruit harvest period, there was rainfall above $30 \mathrm{~mm} /$ liter in the area in which Gelsura was used. This may have triggered a lower residual effect of the formulation, corroborating the results obtained in the simulated rain bioassays.

The results found in the present study indicate that toxic baits are considered promising for use in the management of $A$. fraterculus. In addition, the validation of the use of the Gelsura formulation in the field for $A$. fraterculus population suppression gives producers another management strategy that can be used in apple orchards. This gives the producers the ability to rotate management strategies to prevent the evolution of pest resistance exerted by frequent use of similarly acting chemical insecticides (Couso-Ferrer et al. 2011, Vontas et al. 2011, Arouri et al. 2015). Likewise, the use of the Gelsura formulation reduces the contamination by chemical residues on the fruits, since the bait spray is directed to the plant trunks and leaves in small volumes of liquid per hectare.

Areas using toxic baits should be monitored to observe local climatic conditions, as depending on the formulation used, there may be a greater or lesser residual effect. In addition, during periods known as full crop harvest, where there is a higher prevalence of ripe fruit in orchards, or in the presence of native fruit species, different management strategies can be adopted. In this context, we can highlight the reducing the application intervals of the baits. In this context, we can highlight the reducing the application intervals of the baits. As well as directing and reinforcing applications around the orchard to form a chemical barrier and preventing insects from moving into the orchard from alternative hosts, should be applied. 


\section{Acknowledgments}

We would like to thank the Wiser and Isca Technologies companies for providing the materials used in the experiments. This work was financially supported by the Brazilian Federal Agency for the Support and Evaluation of Graduate Education (CAPES) and the National Council for Scientific and Technological Development (CNPq).

\section{References Cited}

Abbott, W. S. 1925. A method of computing the effectiveness of an insecticide. J. Econ. Entomol. 18: 265-267.

Allen, G., C. J. Halsall, J. Ukpebor, N. D. Paul, G. Ridall, and J. J. Wargent. 2015. Increased occurrence of pesticide residues on crops grown in protected environments compared to crops grown in open field conditions. Chemosphere. 119: 1428-1435.

Arouri, R., G. Le Goff, H. Hemden, V. Navarro-Llopis, M. M'saad, P. Castañera, R. Feyereisen, P. Hernández-Crespo, and F. Ortego. 2015. Resistance to lambda-cyhalothrin in Spanish field populations of Ceratitis capitata and metabolic resistance mediated by P450 in a resistant strain. Pest Manag. Sci. 71: 1281-1291.

Baronio, C. A., D. Bernardi, B. A. J. Paranhos, F. R. M. Garcia, and M. Botton. 2018. Population suppression of Ceratitis capitata (Wiedemann) on table grapes using toxic baits. An. Acad. Bras. Cienc. 90: 3963-3973.

Baronio, C. A., I. X. Schutze, M. Z. Nunes, D. Bernardi, R. Machota, L. C. Bortoli, C. J. Arioli, F. R. M. Garcia, and M. Botton. 2019. Toxicities and residual effect of spinosad and alpha-cypermethrin-based baits to replace malathion for Ceratitis capitata (Diptera: Tephritidae) control. J. Econ. Entomol. 112: 1798-1804.

Bateman, M. A., and T. C. Morton. 1981. The importance of ammonia in proteinaceous attractants for fruit flies (Family: Tephritidae). Aust. J. Agric. Res. 32: 883-903.

Borges, R., R. Machota Jr, M. I. Boff, and M. Botton. 2015. Efeito de iscas tóxicas sobre Anastrepha fraterculus (Wiedemann) (Diptera: Tephritidae). Bioassay 10: 1-8.

Bortoli, L. C., R. Machota Jr, F. R. M. Garcia, M. Botton. 2016. Evaluation of food lures for fruit flies (Diptera: Tephritidae) captured in a citrus orchard of the Serra Gaúcha. Fla. Entomol. 99: 381-384.

Botton, M., C. J. Arioli, R. Machota Jr, M. Z. Nunes, and J. M. Rosa. 2016. Moscas-das-frutas na fruticultura de clima temperado: situação atual e perspectivas de controle através do emprego de novas formulações de iscas tóxicas e da captura massal. Agropecuária Catarinense 29: 103-108.

Broughton, S., and T. Rahman. 2017. Evaluation of lures and traps for male and female monitoring of Mediterranean fruit fly in pome and stone fruit. J. Appl. Entomol. 141: 441-449.

Chueca, P., H. Montón, J. L. Ripollés, P. Castañera, E. Moltó, and A. Urbaneja. 2007. Spinosad bait treatments as alternative to malathion to control the mediterranean fruit fly Ceratitis capitata (Diptera: Tephritidae) in the Mediterranean Basin. J. Pestic. Sci. 32: 407-411.

Couso-Ferrer, F., R. Arouri, B. Beroiz, N. Perera, A. Cervera, V. NavarroLlopis, P. Castañera, P. Hernández-Crespo, and F. Ortegoa. 2011. Crossresistance to insecticides in a malathion-resistant strain of Ceratitis capitata (Diptera: Tephritidae). J. Econ. Entomol. 104: 1349-1356.

Flores, S., L. E. Gomez, and P. Montoya. 2011. Residual control and lethal concentrations of GF-120 (spinosad) for Anastrepha spp. (Diptera: Tephritidae). J. Econ. Entomol. 104: 1885-1891.

Galm, U., and T. C. Sparks. 2015. Natural product derived insecticides: discovery and development of spinetoram. J. Ind. Microbiol. Biotechnol. 43: 185-193.

Gattelli, T., F. F. da Silva, R. N. Meirelles, L. R. Redaelli, and F. K. Dal SoglioI. 2008. Moscas frugívoras associadas a mirtáceas e laranjeira 'Céu' na região do vale do Rio Caí, Rio Grande do Sul, Brasil. Cienc Rural 38: 236-239.

Gazit, Y., S. Gavriel, R. Akiva, and D. Timar. 2013. Toxicity of baited spinosad formulations to Ceratitis capitata: from the laboratory to the application. Entomol. Exp. Appl. 147: 120-125.

Harter, W. R., M. Botton, D. E. Nava, A. D. Grutzmacher, R. S. Gonçalves, R. Machota Jr, D. Bernardi, and O. Z. Zanardi. 2015. Toxicities and residual effects of toxic baits containing spinosad or malathion to control the adult Anastrepha fraterculus (Diptera: Tephritidae). Fla. Entomol. 98: 202-208.

Machota, R., Jr, L. C. Bortoli, F. R. Cavalcanti, M. Botton, and A. D. Grützmacher. 2016. Assessment of injuries caused by Anastrepha fraterculus (Wied.) (Diptera: Tephritidae) on the incidence of bunch rot diseases in table grape. Neotrop. Entomol. 45: 361-368.

Machota, R., Jr, L. C. Bortoli, A. Tolotti, and M. Botton. 2010. Técnica de criação de Anastrepha fraterculus (Wied., 1830) (Diptera: Tephritidae) em laboratório utilizando hospedeiro natural. Bento Gonçalves: Embrapa Uva e Vinho, 2010.23 p. http://www.scielo.br/scielo.php?script=sci_nlinks \& ref $=000105 \&$ pid=S0100-2945201200010001100014\&lng=pt.

Mafra-Neto, A., F. M. De Lame, C. J. Fettig, A. S. Munson, T. M. Perring, L. L. Stelinski, L. L. Stoltman, L. E. J. Mafra, R. Borges, and R. I. Vargas. 2013. Manipulation of insect behavior with Specialized Pheromone and Lure Application Technology (Splat ${ }^{\mathrm{TM}}$ ). ACS Publications, Washington, DC. pp.31-58.

Mangan, R. L., D. S. Moreno, and G. D. Thompson. 2006. Bait dilution, spinosad concentration, and efficacy of GF-120 based fruit fly sprays. Crop Prot. 25: 125-133.

Miller, N. W., R. I. Vargas, R. J. Prokopy, and B. E. Mackey. 2004. State dependent attractiveness of protein bait and host fruit odor to Bactrocera cucurbitae (Diptera: Tephritidae) females. Ann. Entomol. Soc. Am. 97: 1063-1068

Nava, D. E., and M. Botton. 2010. Bioecologia e controle de Anastrepha fraterculus e Ceratitis capitata em pessegueiro. http://www.infoteca. cnptia.embrapa.br/bitstream/doc/889693/4/CPACTDocumento315.pdf. (Accessed on 21 November 2019).

Navarro-Llopis, V., J. Primo, and S. Vacas. 2013. Efficacy of attract-and-kill devices for the control of Ceratitis capitata. Pest Manag. Sci. 69: 478-482.

Nondillo, A., O. Z. Zanardi, A. P. Afonso, A. J. Benedetti, and M. Botton. 2007. Efeito de inseticidas neonicotinoides sobre a mosca-das-frutas Sulamericana Anastrepha fraterculus (Wiedemann) (Diptera: Tephritidae) na cultura da videira. BioAssay 2: 1-9.

Nunes, A., K. Z. Cosaa, K. M. Faggioni, M. L. Z. Costa, R. S. Gonçalves, J. M. M. Walder, M. S. Garcia, and D. E. Nava. 2013. Dietas artificiais para a criação de larvas e adultos da mosca-das-frutas sul-americana. Pesq. Agropec. Bras. 48: 1309-1314.

Pereira-Rêgo, D. R. G., S. M. Jahnke, L. R. Redaelli, and N. Schaffer. 2013. Variação na infestação de mosca-das-frutas (Diptera: Tephritidae) e parasitismo em diferentes fases de frutificação em mirtaceas nativas no Rio Grande do Sul. Entomo Brasilis 6: 141-145.

Piñero, J. C., S. K. Souder, L. E. Gomez, R. F. Mau, and R. I. Vargas. 2011. Response of female Ceratitis capitata (Diptera: Tephritidae) to a spinosad bait and polymer matrix mixture with extended residual effect in Hawaii. J. Econ. Entomol. 104: 1856-1863.

Raga, A., and L. T. Galdino. 2018. Atração fatal. Cultivar HF 109: 20-23.

Revis, H. C., N. W. Miller, and R. I. Vargas. 2004. Effects of aging and dilution on attraction and toxicity of GF-120 fruit fly bait spray for melon fly control in Hawaii. J. Econ. Entomol. 97: 1659-1665.

Robertson, J. L., and H. K. Preisler. 2007. Pesticide bioassays with arthropods. CRC Press, Boca Raton London, NY.

SAS Institute. 2011. Statistical analysis system: getting started with the SAS learning. SAS Institute, Cary, NC.

Stark, J. D., R. Vargas, and N. Miller. 2004. Toxicity of spinosad in protein bait to three economically important tephritid fruit fly species (Diptera: Tephritidae) and their parasitoids (Hymenoptera: Braconidae). J. Econ. Entomol. 97: 911-915.

Vargas, R. I., S. K. Souder, P. Rendon, and B. Mackey. 2018. Suppression of Mediterranean fruit fly (Diptera: Tephritidae) with trimedlure and biolure dispensers in Coffea arabica (Gentianales: Rubiaceae) in Hawaii. J. Econ. Entomol. 111: 293-297.

Vontas, J., P. H. Crespo, K. T. Margaritopoulos, F. Ortego, H. T. Feng, K. D. Mathiopoulos, and J. C. Hsu. 2011. Insecticide resistance in tephritid flies. Pest. Biochem. Phys. 100: 199-205.

Yee, W. L., and D. G. Alston. 2016. Sucrose mixed with spinosad enhances kill and reduces oviposition of Rhagoletis indifferens (Diptera: Tephritidae) under low food availability. J. Entomol. Sci. 51: 101-112. 